\title{
Nitrous Oxide for Labor Analgesia: What We Know to Date
}

\author{
Kirbie Broughton, MD, ${ }^{1}$ Allison G. Clark, MD, ${ }^{1,2}$ Adrienne P. Ray, MD ${ }^{1}$ \\ ${ }^{1}$ Department of Anesthesiology, Ochsner Clinic Foundation, New Orleans, LA ${ }^{2}$ The University of Queensland Faculty of Medicine, Ochsner \\ Clinical School, New Orleans, LA
}

\begin{abstract}
Background: Although nitrous oxide $\left(\mathrm{N}_{2} \mathrm{O}\right)$ has been used since the 1880 s for labor analgesia, its popularity has only recently increased in the United States. In 2011, only 3 centers in the country offered $\mathrm{N}_{2} \mathrm{O}$, but as of 2020, several hundred labor units have adopted its use.

Methods: We reviewed the literature and summarize the mechanism of action, clinical uses, and efficacy of $\mathrm{N}_{2} \mathrm{O}$ for labor analgesia, as well as patient satisfaction related to its use.

Results: $\mathrm{N}_{2} \mathrm{O}$ has several proposed mechanisms of action that make it a viable option for all 3 stages of labor and postpartum procedures. $\mathrm{N}_{2} \mathrm{O}$ has been shown to be a safe option for both mom and baby during labor and delivery. Studies support $\mathrm{N}_{2} \mathrm{O}$ as an analgesic for laboring. Even though $40 \%$ to $60 \%$ of women who use $\mathrm{N}_{2} \mathrm{O}$ convert to a labor epidural analgesia, satisfaction surveys indicate that analgesia is not the only factor contributing to the use of $\mathrm{N}_{2} \mathrm{O}$ during labor.

Conclusion: The use of $\mathrm{N}_{2} \mathrm{O}$ has increased in labor and delivery units across the United States since 2011. Despite inferior analgesic properties compared to epidural analgesia, $\mathrm{N}_{2} \mathrm{O}$ offers a safe alternative for many parturients who want a greater sense of control and mobility.
\end{abstract}

Keywords: Analgesics, labor-obstetric, labor pain, nitrous oxide

Address correspondence to Adrienne P. Ray, MD, Department of Anesthesiology, Ochsner Clinic Foundation, 1514 Jefferson Hwy., New Orleans, LA 70121. Tel: (504) 842-3755. Email: adray@ochsner.org

\section{INTRODUCTION}

Women in the United States have fewer options for pain management than women in many other developed countries. ${ }^{1}$ Most hospitals in the United States offer neuraxial analgesia or intravenous opioids for pain relief during labor. However, many countries have other pain management strategies available such as hypnosis, acupuncture, and electrical stimulation. Most of these options are not routinely offered in the United States. ${ }^{1}$ Nitrous oxide $\left(\mathrm{N}_{2} \mathrm{O}\right)$ has long been used for labor analgesia in some centers, but only since 2011 has it grown in popularity in the United States. While neuraxial techniques are the most effective current option for pain control, ${ }^{2} \mathrm{~N}_{2} \mathrm{O}$ has been shown to provide analgesic properties. ${ }^{3,4}$

In this review, we discuss the history and growing popularity of $\mathrm{N}_{2} \mathrm{O}$, its mechanism of action, maternal and fetal safety, efficacy, and satisfaction when used for labor analgesia.

\section{HISTORY}

The discovery of $\mathrm{N}_{2} \mathrm{O}$ is attributed to English scientist Joseph Priestley in 1772; however, the first reported use of $\mathrm{N}_{2} \mathrm{O}$ for vaginal delivery did not occur until $1881 .^{5}$ Polish physician Stanislav Klikovich used an $80 \% \mathrm{~N}_{2} \mathrm{O} / 20 \%$ oxygen $\left(\mathrm{O}_{2}\right)$ mixture in 25 laboring women and found that it provided analgesia without adverse fetal effects. ${ }^{1}$ The utility of $\mathrm{N}_{2} \mathrm{O}$ progressed during the early 20th century; how- ever, its use was not without challenges. The lack of a systematic device to administer $\mathrm{N}_{2} \mathrm{O}$ and a way to ensure the delivery of safe concentrations were the two greatest limitations to the use of $\mathrm{N}_{2} \mathrm{O}$ in obstetrics. British anesthetist Robert James Minnitt was a pioneer of inhalational analgesia. Minnitt, along with instrument maker Charles King, produced the first gas/air apparatus in 1933. This device allowed women in labor to inhale a mixture of nitrous and air, providing one of the only forms of labor analgesia at the time. After being used for approximately 3 decades, this apparatus was withdrawn because of delivery of the hypoxic mixture of $\mathrm{N}_{2} \mathrm{O}$ and air. ${ }^{6}$ After multiple revisions to the apparatus, the British began using an $\mathrm{N}_{2} \mathrm{O} / \mathrm{O}_{2}$ delivery system-named Entonox-in $1961 .{ }^{7}$ As of 2011 , only 3 US academic centers were using $\mathrm{N}_{2} \mathrm{O}$ for labor analgesia. In 2011, Nitronox (Porter Instrument) became the first US Food and Drug Administration-approved $\mathrm{N}_{2} \mathrm{O}$ delivery system, which is set to deliver a fixed concentration of $50 \%$ $\mathrm{N}_{2} \mathrm{O} / 50 \% \mathrm{O}_{2}$. According to a 2012 review by Collins et al, the University of California, San Francisco, was at the forefront of institutions offering $\mathrm{N}_{2} \mathrm{O}$ for labor analgesia, at that point having offered the option for more than 30 years. ${ }^{1}$ Vanderbilt University and the University of Washington were the next large academic centers to offer $\mathrm{N}_{2} \mathrm{O}$ to parturients, and many other centers have followed. By 2018, more than 500 birthing centers and hospitals across the country had adopted $\mathrm{N}_{2} \mathrm{O}$ use. 8,9 


\section{MECHANISM OF ACTION}

$\mathrm{N}_{2} \mathrm{O}$ is a tasteless, odorless vapor with peak brain concentrations occurring within 60 seconds after the onset of administration. ${ }^{10}$ Among the several proposed mechanisms for the pharmacokinetics of $\mathrm{N}_{2} \mathrm{O}$ are (1) $\mathrm{N}$-methylD-aspartate antagonism, (2) pain perception modulation at the alpha-2 receptors in the dorsal horn of the spinal cord, and (3) the release of endogenous opioids in the brain. These various mechanisms are believed to reduce pain sensitivity and provide analgesia; however, these mechanisms are still not well understood. Despite insufficient evidence on the precise mechanism of action, $\mathrm{N}_{2} \mathrm{O}$ used for labor analgesia has not been associated with any major side effects and is generally well tolerated. However, as with any treatment therapy, $\mathrm{N}_{2} \mathrm{O}$ is associated with adverse reactions and has contraindications to its use. Nausea, vomiting, and dizziness are among the most common maternal side effects, reported by up to $46 \%, 14 \%$, and $23 \%$ of parturients, respectively. ${ }^{7}$ Respiratory depression is rare unless $\mathrm{N}_{2} \mathrm{O}$ is used in the setting of systemic opioids.

With regard to neonatal outcomes, no significant adverse effects have been reported. ${ }^{3,11}$ Stefani and colleagues found no differences in neurobehavioral assessments of neonates of mothers receiving nitrous concentrations of $30 \%$ to $50 \% .^{11}$ Concerns about neurotoxic effects associated with $\mathrm{N}_{2} \mathrm{O}$ were raised when studies on the effects of anesthetics showed neuronal apoptosis in rodents; however, $\mathrm{N}_{2} \mathrm{O}$ by itself caused little or no apoptosis in the infant rat brain. ${ }^{12}$ Likis and colleagues analyzed 29 studies reporting fetal or neonatal outcomes based on umbilical cord gases and Apgar scores and found no significant difference between mothers who received $\mathrm{N}_{2} \mathrm{O}$ during labor vs mothers who did not. $^{3}$

Contraindications to the use of $\mathrm{N}_{2} \mathrm{O}$ are limited and principally include administration to patients at risk for its accumulation in enclosed spaces (ie, pneumothorax, small bowel obstruction). Parturients with congenital heart defects and/or pulmonary hypertension should avoid $\mathrm{N}_{2} \mathrm{O}$ because it increases pulmonary vascular resistance.

Controversy regarding environmental exposure to $\mathrm{N}_{2} \mathrm{O}$ among healthcare workers and its association with increased risk of adverse reproductive outcomes has been ongoing. The use of scavenger systems and vigilant monitoring of exposure levels with dosimetry badges can keep exposure below the National Institute for Occupational Safety and Health (NIOSH) limit of 25 ppm. Long-term effects of $\mathrm{N}_{2} \mathrm{O}$ exposure are unclear; however, compliance with $\mathrm{NIOSH}$ standards is not associated with an increased risk of reproductive complications. ${ }^{1,13}$

\section{CLINICAL USE}

$\mathrm{N}_{2} \mathrm{O}$ can be used for analgesia during the first, second, or third stage of labor; during postpartum procedures (eg, laceration repair, manual extraction of placenta); and to facilitate epidural placement. $\mathrm{N}_{2} \mathrm{O}$ is self-administered via a mask without straps that could keep the mask fixed to the face and potentially lead to excessive drowsiness and/or hypoxia. Studies evaluating the benefits of $\mathrm{N}_{2} \mathrm{O}$ state that the self-administration aspect of $\mathrm{N}_{2} \mathrm{O}$ improves the parturient's sense of control and ability to cope with labor. ${ }^{5,9}$ Some women do not like to be confined to a bed throughout their labor. The majority of neuraxial anesthetics cause weakness of the lower extremities, requiring a patient to remain in bed once the anesthetic is administered. While most $\mathrm{N}_{2} \mathrm{O}$ policies require the patient to remain in bed or a chair during use, the effects dissipate in less than 5 minutes. This short half-life gives the patient freedom to move about when not using $\mathrm{N}_{2} \mathrm{O} .{ }^{14}$ Administration begins with the patient's inhalation that triggers the opening of a negative pressure valve and permits the flow of $\mathrm{N}_{2} \mathrm{O}$. Educating the patient and practicing the correct technique with the patient is critical for successful pain relief. ${ }^{9}$ Because the onset of $\mathrm{N}_{2} \mathrm{O}$ is approximately 30 to 50 seconds, it should be initiated prior to the onset of a contraction so that peak serum concentrations are present at the height of the contraction.

\section{EFFICACY AND SATISFACTION}

Varying results regarding the effectiveness of $\mathrm{N}_{2} \mathrm{O}$ for labor analgesia have been reported.,4 A 2002 systematic review of 11 trials examining the efficacy of $\mathrm{N}_{2} \mathrm{O}$ revealed the complexity of this assessment. ${ }^{4}$ Several factors are responsible for the variability of findings: concentration of $\mathrm{N}_{2} \mathrm{O}$ used, method of administration, administration of other intravenous medications, and unsatisfactory study design. Because of this variability, drawing conclusions about the efficacy of $\mathrm{N}_{2} \mathrm{O}$ is difficult. In a postpartum survey of 2,482 Swedish women, $84 \%$ of nulliparous and $72 \%$ of parous women rated neuraxial techniques as very effective compared to $38 \%$ of nulliparous and $49 \%$ of parous women who rated $\mathrm{N}_{2} \mathrm{O}$ as very effective. ${ }^{15}$ Despite the lower percentage of satisfied parturients who used $\mathrm{N}_{2} \mathrm{O}$, the study provides evidence that $\mathrm{N}_{2} \mathrm{O}$ has analgesic benefit. In a study comparing various analgesic modalitiesincluding $\mathrm{N}_{2} \mathrm{O}$, epidural alone, and epidural following other modalities (eg, $\mathrm{N}_{2} \mathrm{O}$, meperidine) $-33 \%$ of patients who used nitrous alone rated its analgesia as good. ${ }^{16}$ Subsequent studies continued to show a wide range of analgesic efficacy. ${ }^{3,9}$ Importantly, based on postpartum surveys of labor and delivery experience, analgesia is not the only factor associated with satisfaction. Other factors such as bodily sensations of labor, mobility, and perceived situational control are also major determinants of labor and delivery experience. $^{9}$

\section{PREDICTORS OF SUCCESS}

Sutton et al retrospectively analyzed the use of $\mathrm{N}_{2} \mathrm{O}$ and predictors of conversion to epidural labor analgesia. ${ }^{17}$ Three percent of parturients used $\mathrm{N}_{2} \mathrm{O}$ during the study period; the majority were nulliparous $(71.2 \%)$, and more than half (51.9\%) expressed preference for a nonmedical birth. Of the 146 women included in the analysis, $63 \%$ converted from $\mathrm{N}_{2} \mathrm{O}$ to neuraxial analgesia. Factors associated with conversion from $\mathrm{N}_{2} \mathrm{O}$ to neuraxial analgesia were labor induction, labor augmentation, and lower cervical dilation at the time of $\mathrm{N}_{2} \mathrm{O}$ request. ${ }^{17}$ Richardson et al analyzed qualitative comments from women who used $\mathrm{N}_{2} \mathrm{O}$ for labor to try to better understand the determinants of satisfaction despite variable analgesic effects. Of the 264 women who responded, $90 \%$ were highly satisfied with their use of $\mathrm{N}_{2} \mathrm{O}$ for labor. Many of these women reported coping benefits of $\mathrm{N}_{2} \mathrm{O}$, such as relaxation, reduced anxiety, and dissociation from pain. Richardson et al reported that among patients who used $\mathrm{N}_{2} \mathrm{O}$ and delivered vaginally, $40 \%$ converted to neuraxial analgesia. $^{9}$ 


\section{CONCLUSION}

Despite its long history, $\mathrm{N}_{2} \mathrm{O}$ is a relatively new option for labor analgesia in the United States. While the mechanism of action of $\mathrm{N}_{2} \mathrm{O}$ is unclear and pain relief does not compare to the efficacy of neuraxial techniques, evidence shows that $\mathrm{N}_{2} \mathrm{O}$ provides analgesic benefit in labor. The many advances made in the $\mathrm{N}_{2} \mathrm{O}$ delivery system ensure that parturients receive safe concentrations, and, despite common side effects, no serious adverse effects have been reported. Despite some studies reporting suboptimal pain control, $\mathrm{N}_{2} \mathrm{O}$ offers situational control, mobility, and bodily sensation in labor that are associated with greater satisfaction among some parturients. The increasing availability of $\mathrm{N}_{2} \mathrm{O}$ shows promise for improved management of labor pain for women and opens the door for further advancement in options available to laboring parturients.

\section{ACKNOWLEDGMENTS}

The authors have no financial or proprietary interest in the subject matter of this article.

\section{REFERENCES}

1. Collins MR, Starr SA, Bishop JT, Baysinger CL. Nitrous oxide for labor analgesia: expanding analgesic options for women in the United States. Rev Obstet Gynecol. 2012;5(3-4):e126-e131.

2. Anim-Somuah M, Smyth R, Howell C. Epidural versus non-epidural or no analgesia in labour. Cochrane Database Syst Rev. 2005 Oct 19;19(4):CD000331.

3. Likis FE, Andrews JC, Collins MR, et al. Nitrous oxide for the management of labor pain: a systematic review. Anesth Analg. 2014 Jan;118(1):153-167. doi: 10.1213/ANE.0b013e3182a7f73c.

4. Rosen MA. Nitrous oxide for relief of labor pain: a systematic review. Am J Obstet Gynecol. 2002 May;186(5 Suppl Nature):S110-S126.

5. Frost EA. A history of nitrous oxide. In: Eger Elll, ed. Nitrous Oxide/N2O. New York, NY: Elsevier Inc; 1985:1-22.

6. O'Sullivan EP. Dr Robert James Minnitt 1889-1974: a pioneer of inhalational analgesia. J R Soc Med. 1989 April;82(4):221-222. doi: $10.1177 / 014107688908200413$.
7. Richardson MG, Lopez BM, Baysinger CL. Should nitrous oxide be used for laboring patients? Anesthesiol Clin. 2017 Mar;35(1):125-143. doi: 10.1016/j.anclin.2016.09.011.

8. Camann WR, Vallejo MC, Carvalho B, et al. How to say "YES" to nitrous oxide for labor analgesia. SOAP Newsletter. 2015 Summer;22-24.

9. Richardson MG, Raymond BL, Baysinger CL, Kook BT, Chestnut $\mathrm{DH}$. A qualitative analysis of parturients' experiences using nitrous oxide for labor analgesia: it is not just about pain relief. Birth. 2019 Mar;46(1):97-104. doi: 10.1111/birt.12374.

10. Maze $M$, Fujinaga $M$. Recent advances in understanding the actions and toxicity of nitrous oxide. Anaesthesia. 2000 Apr;55(4):311-314. doi: 10.1046/j.1365-2044.2000.01463.x.

11. Stefani SJ, Hughes SC, Shnider SM, et al. Neonatal neurobehavioral effects of inhalation analgesia for vaginal delivery. Anesthesiology. 1982 May;56(5):351-355.

12. Creeley CE, Olney JW. The young: neuroapoptosis induced by anesthetics and what to do about it. Anesth Analg. 2010 Feb;110(2):442-448. doi: 10.1213/ANE.0b013e3181c6b9ca.

13. Rooks JP. Safety and risks of nitrous oxide labor analgesia: a review. J Midwifery Womens Health. 2011 Nov-Dec;56(6):557-565. doi: 10.1111/j.1542-2011.2011.00122.x.

14. O'Reilly JE, Roth GI, Matheny JL, Falace DA, Norton JC. The effects of nitrous oxide administration in the healthy elderly: N2O elimination and alveolar CO2. Anesth Prog. 1983 Nov-Dec;30(6):187-192.

15. Waldenström $U$, Irestedt L. Obstetric pain relief and its association with remembrance of labor pain at two months and one year after birth. J Psychosom Obstet Gynaecol. 2006 Sep;27(3):147-156. doi: 10.1080/01674820500433432.

16. Ranta $P$, Jouppila $P$, Spalding $M$, Kangas-Saarela $T$, Hollmén $A$, Jouppila R. Parturients' assessment of water blocks, pethidine, nitrous oxide, paracervical and epidural blocks in labour. Int $J$ Obstet Anesth. 1994 Oct;3(4):193-198. doi: 10.1016/0959-289x(94)90067-1.

17. Sutton CD, Butwick AJ, Riley ET, Carvalho B. Nitrous oxide for labor analgesia: utilization and predictors of conversion to neuraxial analgesia. J Clin Anesth. 2017 Aug;40:40-45. doi: 10.1016/j.jclinane.2017.04.005.

This article meets the Accreditation Council for Graduate Medical Education and the American Board of Medical Specialties Maintenance of Certification competencies for Patient Care and Medical Knowledge.

(C2020 by the author(s); licensee Ochsner Journal, Ochsner Clinic Foundation, New Orleans, LA. This article is an open (c) (i) access article distributed under the terms and conditions of the Creative Commons Attribution (CC BY) license (creativecommons.org/licenses/by/4.0/legalcode) that permits unrestricted use, distribution, and reproduction in any medium, provided the original author(s) and source are credited. 